\title{
In vitro antibacterial activity of Peganum harmala (L) extract to some fish pathogenic bacteria
}

\author{
PAkbary $^{1}$, M S Fereidouni ${ }^{2}$ and M Akhlaghi ${ }^{2}$ \\ ${ }^{1}$ Department of Marine Sciences, Chabahar Maritime University, Iran \\ ${ }^{2}$ Aquatic Animal Health Unit, School of Veterinary Medicine, Shiraz University, Shiraz, Iran
}

Received: February 2014

Accepted: June 2014

\begin{abstract}
This study was conducted to examine in vitro antibacterial potential from seed methanol extract of Peganum harmala (L) against some fish pathogenic bacteria including Lactococcus garvieae, Aeromonas hydrophila, Yersinia ruckeri and Pseuodomonas putida isolated from diseased rainbow trout (Oncorhynchus mykiss). The antibacterial activity of extracts was evaluated using disc diffusion assay, minimum inhibitory concentration (MIC) and minimum bactericidal concentration (MBC). MICS were measured by serial dilution and the microplate assays. Results showed that the methanol extract of P. harmala was bactericidal for all test bacteria. The MICs of extract using serial dilution and microplate method were $0.6 \mathrm{mg} \mathrm{mL}^{-1}$ and 0.312 to $0.625 \mathrm{mg}$ $\mathrm{mL}^{-1}$ against $P$. putida and $0.8 \mathrm{mg} \mathrm{mL}^{-1}$ and 0.625 to $1.25 \mathrm{mg} \mathrm{mL}^{-1}$ against L. garvieae, A. hydrophila, Y. ruckeri, respectively which was confirmed by MBC determination. Thus, the antibacterial activity of seed extract of $P$. harmala can be comparable as an alternative in the control of infectious by these microorganisms.
\end{abstract}

Key words: Peganum harmala, seed extracts, fish pathogenic bacteria, antibacterial activity.

\section{Introduction}

During last decades, there has been a steady growth

Correspondence P Akbari, Department of Marine Sciences, Chabahar Maritime University, Iran (e-mail: paria.akbary@, gmail.com) of aquaculture industries all over the world andsuch intensive production would experience disease problems. Infectious diseases which have been occurred sporadically in wild -fish populations may cause high mortalities when appearing in intensive fish farming (Gudding, Lillehaug \& Evensen 1999). Many bacterial diseases in aquaculture are controlled by antibiotics. However, continuous use of antibiotics leads to drug resistance and thereby to a reduced efficiency of the drugs. Antibiotics which have been accumulated in the environment and fish, pose a potential risk to consumers and to the environment alike (Bektas \& Ayik 2011).

Antibiotics and other chemical disinfectants are widely utilized to prevent bacterial disease in fish. Due to bacterial pathogens, particularly Lactococcus garvieae (Haghighi Karsidani, Soltani, Nikbakhat-Brojeni, Ghasemi \& Skall 2010), Aeromonas hydrophila (John, Rathna Kumari \& Balasundaram 2011), Yersinia ruckeri (Tobback, Decostere, Hermans, Haesebrouck \& Chiers 2007) and Pseuodomonas putida (Altınok, Kayis \& Capkin 2006 ) in rainbow trout, the rapidly expanding aquaculture industry has suffered from heavy economic losses. Increased public awareness of the negative effects, which caused by overexposure to synthetic chemicals, has led to the search for "green solutions" such as organic and synthetic chemical- free food products (Abutbul, Golan-Goldhirsh, Barazani \& Zilberg 2004; Fereidouni, Akhlaghi \& Khadem Alhosseini 2013). For organic fish production, it is essential to develop antibacterial treatments that are made from materials with natural sources.

Medicinal herbs contain physiologically active gradients that over the years have been exploited in traditional medicine for the treatment of various ail- 
ments because of having anti- microbial properties (Kelmanson, Jager \& Van Staden 2000; Srinivasan, Sangeetha, Suresh \& Perumalsamy 2001; Ghasemi Pirbalouti, Nikobin Broujeni, Momenii, Malekpoor \& Hamed 2011; Negi, Singh \& Rawat 2011). Peganum harmala L. (Zygophyllaceae), that has been also called Harmal or Suryin Rue, is a perennial, bushy and wild-growing flowering plant with short creeping root which may grow to $30-100 \mathrm{~cm}$ high (Mahmoodian, Jalilpour \& Salehian 2002; Shamsa, Monsef, Ghamooghi \& Verdian Rizi 2007; Goel, Singh \& Saini 2009) is known as "Espand" in Iran and Harmal in North Africa and African Rue, Mexican Rue, Syrian Rue or Turkish Rue in United States (Mahmoodian et al. 2002). This plant is widely distributed in North Africa, Mediterranean, the Middle East, Pakistan, India and Iran and has been introduced in America and Australia (Asghari \& Lockwood 2002; Ehsanpour \& Saadat 2002; Yousefi, Ghaffarifar \& Dalimi 2009). P. harmala traditionally has been used in Iran as an antiseptic and disinfectant agent by burning its seeds (Fathiazada, Azarmi \& Khodaie 2006; Arshad, Zitterl-Eglseer, Hasnain \& Hess 2008). It has been considered for the treatment of a variety of human ailments such as lumbago, asthma, colic, jaundice (Bukhari et al. 2008). The most pharmacological active compounds of $P$. harmala are several alkaloids which have been found in the seeds and roots (Mirzaie, Nosratabadi, Derakhshanfar \& Sharifi 2007). It has also been reported that this plant had antibacterial, antifungal and antiviral effects (Shonoudam, Osman, Salama \& Ayoub 2008).

In spite of considerable efforts to provide an alternative to medicinal plants with minimum side effects, easy accessibility, and excellent compatibility, future clinical trials as well as standardization of medicinal plants are still required as an important step in drug discovery (John et al. 2011). The aim of the present study was initially to assess the antibacterial property of the seed methanol extract of $P$. harmala against some of the most important rainbow trout (Oncorhynchus mykiss) pathogenic bacteria to provide useful information on the efficacy of antimicrobial treatments in rainbow trout.

\section{Materials and Methods}

\section{Extract preparation}

P. harmala medicinal plant was collected from herbal medicine shop and its identity was confirmed using monographs by Mozaffarian (1996).

The seeds of the plant were shade- dried and ground into a powder $(50 \mathrm{~g})$, macerated in $400 \mathrm{~mL}$ of methanol, filtered, and dried at $35^{\circ} \mathrm{C}$ using a rotary vacuum. Then, the extract of sample was stored in the bottle and refrigerated at $4{ }^{\circ} \mathrm{C}$ prior to further analyses.

\section{Bacterial strain}

Strains of L. garvieae (EU727199; Sharifiyazdi, Akhlaghi, Tabatabaei \& Mostafavi Zadeh 2010), A. hydrophila (JF313402; Dehghani, Akhlaghi \& Dehghani 2012), Y. ruckeri (ATCC29475; Akhlaghi \& Sharifi Yazdi 2008) and P. putida (JN937120; Hedayatian, Sharifiyazdi \& Akhlaghi 2010) were isolated from the infected rainbow trout from commercial aquaculture farms in Fars Province, Iran (obtained from the Shiraz University, Shiraz, Iran). The isolated bacteria were cultured on blood agar by the use of streaking method and incubation at $30{ }^{\circ} \mathrm{C}$ overnight, aerobically. On the next day, colonies revealing characteristics of test bacteria were selected for further analyses such as Gram stainingand biochemical tests. It was then confirmed by molecular methods (Ravelo, Magarinos, Romalde \& Toranzo 2001; Austin \& Austin 2007; Calist \& Ruzzi 2009; Trakhna, Harf-Monteil, Abdelnour, Maaroufi \& Gadonna-Widehem 2009).

The bacteria were kept frozen in $15 \%$ glycerol, $85 \%$ saline solution or Brain Heart Infusion (BHI) broth, in aliquots, at $-70^{\circ} \mathrm{C}$ until used. For infection trials, $100 \mathrm{mLof}$ BHI broth was inoculated with $50 \mu \mathrm{L}$ of the frozen isolates. The cultures were shaken (100 rpm) at $27{ }^{\circ} \mathrm{C}$ for $48 \mathrm{~h}$. Absorbance (at $600 \mathrm{~nm}$ ) of known bacterial densities were determined to obtain a standard calibration curve. An initial bacterial suspension containing $10^{7} \mathrm{CFU} \mathrm{mL}{ }^{-1}$ was made from the flask broth culture. Subsequent dilutions were made from the above suspension, which were then utilized in tests. 


\section{Disc diffusion assay}

The disc diffusion assays of Lennette (1985) were used with some modification to determine the growth inhibition of extract on all test bacteria. Muller Hinton (MH) agar (Merck, Germany) was used to prepare the culture medium and autoclaved at $121{ }^{\circ} \mathrm{C}$ for $15 \mathrm{~min}$. Briefly, plates $(8-\mathrm{cm}$ diameter) were prepared with $10 \mathrm{~mL} \mathrm{MH}$ agar inoculated with $1 \mathrm{~mL}$ of bacterial suspension $\left(10^{7} \mathrm{CFU} \mathrm{mL} \mathrm{mL}^{-1}\right)$. The extracts were dissolved in dimethyl sulfoxide (DMSO, $15 \mu \mathrm{L}$ ) before being tested for antimicrobial activity. Sterile paper discs (5 $\mathrm{mm}$ in diameter) were impregnated with $20 \mu \mathrm{L}$ of different concentrations of extract $\left(50,100,200,300\right.$ and $\left.400 \mathrm{mgmL}^{-1}\right)$ placed onto nutrient agar. The plates were incubated at $35^{\circ} \mathrm{C}$ for $18 \mathrm{~h}$. Negative controls which were prepared using the same solvent employed to dissolve the plant extract. Tetracycline and chloramphenicol $(30 \mu \mathrm{g})$ were tested in the same conditions as positive controls.

Inhibition zones in $\mathrm{mm}$ (without disc paper diameter) around discs were measured. Theantibacterial activity was characterizedas the diameter of inhibition zones produced by the extract against test microorganisms. The experiment was repeated in triplicate and the mean of diameter of the inhibition zones was calculated.

\section{Minimal inhibitory concentration assay}

To determine the minimal inhibitory concentrations (MICs) of antimicrobial agents, serial dilution and microplate assays were used. The MIC was defined as the lowest concentration of the extract to inhibit the growth of the microorganism to $50 \%$.

\section{Serial dilution assay}

MICs were determined by broth dilution method in culture tubes (Jorgensen, Turnidge \& Washington 1999.) with some modification. The extract was initially tested at $2 \mathrm{mg} \mathrm{mL}^{-1}$ and serially diluted from 2 to $0.04 \mathrm{mg} \mathrm{mL}^{-1}$. Then, each tube was inoculated with $1 \mathrm{~mL}$ of suspension containing $10^{7} \mathrm{CFU} \mathrm{mL}^{-1}$ of each bacterium and incubated at $25^{\circ} \mathrm{C}$ for $24 \mathrm{~h}$. Erythromycin was included as a positive control in each assay. Extract-free solution was used as a negative control. Control tubes were incubated under the same condition. The tubes were examined for visible growth or lack of growth for each dilution of test bacteria. Turbidity indicated growth of the microorganism and the MIC was the lowest concentration in which no growth was visually observed (Jorgensen et al. 1999).

\section{Minimum bactericidal concentration assay}

The MBC values of the extract were determined by the drop plate method from the tubes, which no visible growth found apparently according to Kowser $\&$ Fatema (2009). Some modifications were made to the method. The Minimal Bactericidal Concentration (MBC) assay was conducted as an adjunct to the MIC and was used to determine the concentration of extract which was lethal to the target bacteria in vitro. From each MIC broth tube without visible growth, $25 \mu \mathrm{l}$ volume of the broth was aliquot onto Nutrient agar and spread across the entire surface of the plate. Then, the dilution of the sub cultured MIC tube was recorded on each plate and incubated at $25^{\circ} \mathrm{C}$ for $24 \mathrm{~h}$. The MBC plates were analyzed for colony growth or lack of growth for each dilution sub cultured. No growth indicated that the extract was bactericidal at that dilution; Growth revealed that the extract was bacteriostatic but not bactericidal at that dilution.

\section{Microplate assay}

The method of Stubbings, Bostock, Ingham \& Chopra (2004) with some modification was used to determine the MIC of extract against all of test bacteria. Sterile 96-well microplates were utilized for the assay. The stock extract was dissolved in DMSO (no more than 5\%). All wells (two rows for each microorganism) were filled with TSB $(1 \mathrm{~mL})$. Test extract $(1 \mathrm{~mL})$ was added to the first well of each row and serial two-fold dilutions $(0.019$ to $10 \mathrm{mg}$ $\mathrm{mL}^{-1}$ ) were made down to the desired minimum concentration. The wells (two rows for each microorganism) were inoculated with the suspension of each test bacteria $(0.1 \mathrm{~mL}$ of $0.5 \mathrm{McF}$ arland Standard) and incubated at $37^{\circ} \mathrm{C}$ overnight. The growth 
of each microorganism in the different dilutions of extract was determined by measuring the optical density at $600 \mathrm{~nm}$ with a spectrophotometer. The well filled with TSB medium and the suspension of each test bacteria was included as a positive control in each assay. The well filled with TSB medium and extract was used as a negative control. All assays were carried out in triplicate. The inhibition demonstrated by the extract is expressed by the following equation (Zampini,Vattuone \& Isla 2005): Inhibition $\%=[(\mathrm{OD} \mathrm{c}-\mathrm{OD} \mathrm{t}) / \mathrm{OD} \mathrm{c}] \times 100$ where ODc is the OD600 for the negative control (containing no extract) and OD $t$ is the OD600 for the sample treated with the antimicrobial compounds.

\section{Statistical analysis}

Experiments were conducted in triplicate and results were expressed as mean \pm standard deviation (SD). A comparison of antibacterial activity of the extract against all test bacteria with standard antibiotics was evaluated by applying a two tailed- unpaired t- test. The comparison and difference between all test bacteria were evaluated by using one- way analysis of variance (ANOVA) and Duncan multiple comparisons test, respectively. Bacterial strains were considered to be significantly different if $\mathrm{P}<0.05$. All statistics were performed using SPSS for windows version 16 (Chicago, IL., USA).

\section{Results}

Table 1 presents diameters of inhibition zones exerted by the different concentrations of extract and the two standards (tetracycline and chloramphenicol) towards tested microorganisms. P. harmala seeds extract was effective against all tested bacterial strains. Higher inhibition was detected against A. hydrophila, Y. ruckeri and L. garvieae compared with P. putida $(\mathrm{P}<0.05)$. The activity of seed extract was higher than that of tetracycline for all tested microorganisms. In the case of $A$. hydrophila and Y. ruckeri, the activity of seed extract $(21 \pm 2.95$, $19 \pm 4.12$ respectively) was lower than that of chloramphenicol (29 $\pm 2.25,23 \pm 3.91$ respectively).

Subsequent experiment was conducted to determine the growth inhibition values (\%) and MIC deter- mination of different concentrations of methanol extract of $P$. harmala for all test bacterial strains using serial dilution (Table2) and microplate assay (Fig.1). The extract showed strong antibacterial activity against all test bacteria and the MIC values of extract using serial dilution (Table 2) and microplate method (Fig. 1) were $0.6 \mathrm{mg} \mathrm{mL}^{-1}$ and 0.312 to $0.625 \mathrm{mg} \mathrm{mL}^{-1}$ against $P$. putida and $0.8 \mathrm{mg} \mathrm{mL}^{-1}$ and 0.625 to $1.25 \mathrm{mg} \mathrm{mL}^{-1}$ against L. garvieae, $A$. hydrophila and Y. ruckeri, respectively. There were significant differences in the antibacterial activities of different concentrations of $P$. harmala extract on L. garvieae, A. hydrophila, Y. ruckeri and P. putida strains $(\mathrm{P}<0.05)$. As Figure 1 illustrates, among the bacterial strains tested, Y. ruckeri and P. putida revealed the lowest growth in different concentrations of methanol extract of $P$. harmala seeds which were studied. Moreover, the methanol extract at different doses had different potential which increase with dose. As can be seen from Table 2, MBC assay performed as an adjunct to the MIC showing that For P. putida and Y. ruckeri, the MBC of extract was observed in $0.8 \mathrm{mg} \mathrm{mL}^{-1}$ and for L. garvieae and $A$. hydrophila was found in $1.1 \mathrm{mg} \mathrm{mL}^{-1}$.

\section{Discussion}

In recent years, a great spread of multidrug-resistant (MDR) bacterial pathogens has become a serious concern worldwide in terms of public health and economic impacts. Enhanced public awareness of the negative effects caused by overexposure to synthetic chemicals has led to the search for "green solutions" such as organic and synthetic chemicalfree food products (Abutbul et al. 2004; Fereidouni et al. 2013). For organic fish production, it is necessary to develop antibacterial treatments that are made from materials with natural sources.

In the present study, the activity of seed extract was higher than that of tetracycline for all tested microorganisms. Also, higher inhibition was detected against A. hydrophila, Y. ruckeri and L. garvieae in comparison with $P$. putida (Table 1). It shows that $P$. harmala extract as a natural and environmental friendly compound can be considered as an important source of antibacterial agent against the three 


\section{Iranian Journal of Aquatic Animal Health}

Table 1 The Inhibition zones around the discs $(\mathrm{mm})$ produced by antibacterialactivity of different concentrations of P.harmala (mg $\mathrm{mL}^{-1}$ ) and standard antibiotics (tetracycline and chloramphenicol) against bacterial strains isolated from rainbow trout

\begin{tabular}{lllllllll}
\hline bacterial strains & \multicolumn{7}{c}{ Concentration $\left(\mathrm{mg} \mathrm{mL}^{-1}\right)$} \\
& 50 & 100 & 200 & 300 & 400 & 500 & tetracycline & chloramphenicol \\
\hline A.hydrophila & $25 \pm 3.13$ & $16 \pm 1.78$ & $18 \pm 3.10$ & $21 \pm 4.12$ & $21 \pm 3.80$ & $21 \pm 2.95$ & $18 \pm 3.11$ & $29 \pm 2.25$ \\
P. putida & $\mathrm{ND}$ & $\mathrm{ND}$ & $8 \pm 1.11$ & $11 \pm 3.23$ & $12 \pm 3.76$ & $13 \pm 1.20$ & $12 \pm 3.74$ & $\mathrm{ND}$ \\
L.garvieae & $13 \pm 1.78$ & $17 \pm 2.12$ & $18 \pm 2.54$ & $20 \pm 1.12$ & $20 \pm 1.33$ & $20 \pm 1.23$ & $14 \pm 1.88$ & $19 \pm 4.12$ \\
Y.ruckeri & $16 \pm 2.25$ & $18 \pm 2.21$ & $19 \pm 3.34$ & $19 \pm 3.98$ & $19 \pm 4.21$ & $19 \pm 4.12$ & $18 \pm 2.74$ & $23 \pm 3.91$ \\
\hline
\end{tabular}

Each data point represents the mean $( \pm$ S.D.) of triplicates. Data are identified by unpaired t- test.$N D$ : not determined.

Table 2 Determination of MIC (by serial dilution assay) and MBC in different concentrations of P.harmala $\left(\mathrm{mg} \mathrm{mL}^{-1}\right)$ against bacterial strains isolated from rainbow trout

\begin{tabular}{|c|c|c|c|c|c|c|c|c|c|c|c|c|c|c|}
\hline \multirow[t]{4}{*}{ bacterial strains } & \multicolumn{14}{|c|}{ Concentration $\left(\mathrm{mg} \mathrm{mL}^{-1}\right)$} \\
\hline & 2 & 1.5 & 1.1 & 0.8 & 0.6 & 0.47 & 0.35 & 0.26 & 0.20 & 0.15 & 0.10 & 0.08 & 0.06 & 0.04 \\
\hline & $\mathrm{MIC} /$ & $\mathrm{MIC} /$ & $\mathrm{MIC} /$ & $\mathrm{MIC} /$ & $\mathrm{MIC} /$ & $\mathrm{MIC} /$ & $\mathrm{MIC} /$ & $\mathrm{MIC} /$ & $\mathrm{MIC} /$ & $\mathrm{MIC} /$ & $\mathrm{MIC} /$ & $\mathrm{MIC} /$ & $\mathrm{MIC} /$ & $\mathrm{MIC} /$ \\
\hline & $\mathrm{MBC}$ & $\mathrm{MBC}$ & $\mathrm{MBC}$ & $\mathrm{MBC}$ & $\mathrm{MBC}$ & $\mathrm{MBC}$ & $\mathrm{MBC}$ & $\mathrm{MBC}$ & $\mathrm{MBC}$ & $\mathrm{MBC}$ & $\mathrm{MBC}$ & $\mathrm{MBC}$ & $\mathrm{MBC}$ & $\mathrm{MBC}$ \\
\hline A.hydrophila & $-/-$ & $-/-$ & $-/-$ & $-1+$ & $+1+$ & $+1+$ & $+1+$ & $+1+$ & $+1+$ & $+1+$ & $+1+$ & $+1+$ & $+/+$ & $+1+$ \\
\hline P. putida & $-/-$ & $-1-$ & $-1-$ & $-1-$ & $-1+$ & $+1+$ & $+/+$ & $+1+$ & $+/+$ & $+1+$ & $+1+$ & $+1+$ & $+/+$ & $+1+$ \\
\hline L.garvieae & $-1-$ & $-/-$ & $-1-$ & $-1+$ & $+1+$ & $+1+$ & $+1+$ & $+1+$ & $+1+$ & $+1+$ & $+1+$ & $+1+$ & $+1+$ & $+1+$ \\
\hline Y.ruckeri & $-1-$ & $-1-$ & $-1-$ & $-1-$ & $+1+$ & $+1+$ & $+1+$ & $+1+$ & $+1+$ & $+1+$ & $+1+$ & $+1+$ & $+1+$ & $+1+$ \\
\hline
\end{tabular}

$(+)$ visible growth of each microorganism (-) No growth of each microorganism.

Gram- negative bacteria including A. hydrophila, $Y$. ruckeri, P. putida and L. garvieae as a Gram- positive. Bacterial pathogens could be controlled by a health management protocol using disinfectants such as natural antibacterial compound besides employing vaccination of fish against the etiological agent. It should be noted, however, that such antibacterial with a natural source is not expensive and could be prepared and ordered by registered agencies around the world. The sensitivity of $L$. garvieae to seed extract of $P$. harmala is consistent with published data by Fereidouni et al. (2013); however, the results are difficult to compare because literature assays were carried out at different conditions. They showed inhibitory effects of seed extract of $P$. harmala on growth of L. garvieae, with an inhibition zone of $28 \mathrm{~mm}$ (Fereidouni et al. 2013). Darabpour, Poshtkouhian Bavi, Motamedi \& Seyyed Nejad (2011) found a remarkable antibacterial effect of extracts of root and seed of $P$. harmala against Gram positive bacterial species including Bacillus anthracis, Bacillus cereus, Bacillus pumilus, Staphylococcus aureus, Staphylococcus epidermidis, Listeria monocytogenes, Streptococcus pyogenes and Gram negative bacterial species including Pseudomonas aeruginosa, Brucella melitensis, Proteus mirabilis, Salmonella typhi, Escherichia coli and Klebsiella pneumoniae. They also reported that among the evaluated parts of $P$. harmala, the root and seed extracts presented antibacterial activity against all of tested bacteria even at the lowest concentration. The Antibacterial effect of leaf part was moderate while stem and flower extracts showed relatively poor activity.

Likewise, Amel, Abdlouahab \& Abdlhakim (2012) have reported an inhibitory effect of seed alkaloid extract of $P$. harmala against some gram positive bacterial strains such as Staphylococcus aureus and Staphylococcus saprophyticus and gram negative such as Escherichia coli, Klebsiellapneumoniae, Pseudomonas aeruginosa, Proteus mirabilis and Serratia spp, The diameters of inhibition zones ranged from 11 to $22 \mathrm{~mm}$ for all treatments.

Also, this finding was in coincidence with Cowan (1999) and Al-Mizrakchi (1998) 'studies who discovered that $P$. harmala extract (aqueous and alcoholic) is very effective against all gram positive bacteria including Lactobacilli and Streptococcus 


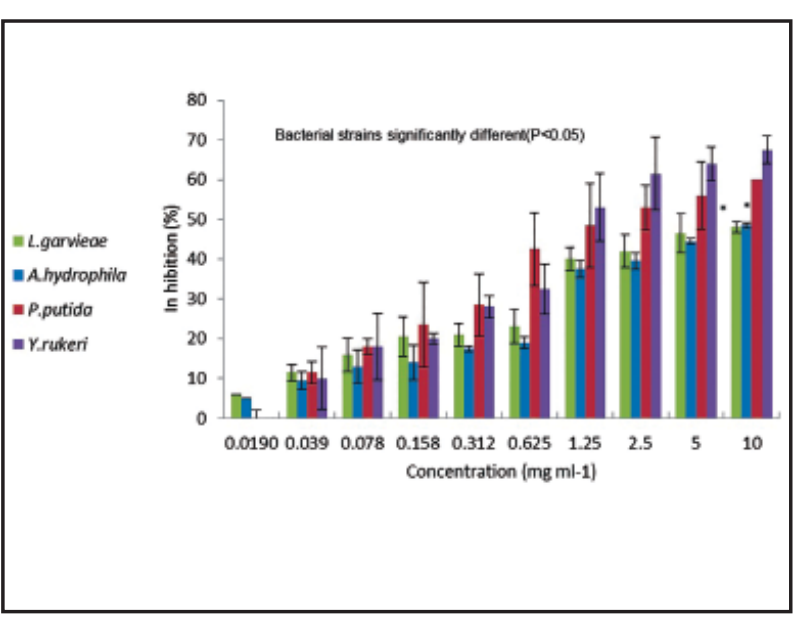

Figure 1 The growth inhibition values (\%) and MIC determination of different concentrations of methanolextract of P.harmala $\left(\mathrm{mg} \mathrm{mL}^{-1}\right)$ for all test bacteria using microplate assay. Each data point represents the mean $( \pm$ S.E. $)$ of triplicates. Data are identified by Duncan's test. The growth inhibition valuesthat are similar among bacteria strains are identified by * symbol.

mutans, respectively. Other studies have revealed the sensitivity of $A$. hydrophilla strain to seed aqueous extract of $P$. harmala. That is, they showed inhibitory effects on growth of $A$. hydrophila, with inhibition zone $20.5 \mathrm{~mm}$ (Abutbul et al. 2004).

In the present study, increasing doses of methanol extract of $P$. harmala from $0.019 \mathrm{mg}$ to $10 \mathrm{mg}$ caused increase in the average growth inhibition of all tested bacteria, which, in turn, revealed that the ability of antibacterial effects enhance with increasing doses or concentrations of metabolic substances. This finding suggested that other components of $P$. harmala be identified and examined on growth of bacteria. Its antibacterial effect against MRSA (Methicillin Resistant Staphylococcus aureus) was surveyed by Moghadam, Maleki, Darabpour, Motamedi \& Seyyed Nejad (2010). They prepared ethanolic extract from this plant and tested itby disk diffusion method. Their results showed that $P$. harmala extract has high antibacterial activity against MRSA isolates and this activity was increased in accordance with its concentration $\left(400 \mathrm{mg} \mathrm{mL}^{-1}\right)$. The MIC values of extract using serial dilution (Table 3) and microplate method (Fig. 1) were $0.6 \mathrm{mg}$ $\mathrm{mL}^{-1}$ and 0.312 to $0.625 \mathrm{mg} \mathrm{mL}^{-1}$ against P. putida and $0.8 \mathrm{mg} \mathrm{mL}^{-1}$ and 0.625 to $1.25 \mathrm{mg} \mathrm{mL}^{-1}$ against L. garvieae, A. hydrophila and Y. ruckeri, respectively. Aligiannis, Kalpotzakis, Mitaku and Chinou
(2001) have proposed a classification of plant extracts on the basis of their MIC values as: strong inhibition: $\mathrm{MIC}<500 \mu \mathrm{g} \mathrm{mL}^{-1}$; moderate inhibition: $600 \mu \mathrm{g} \mathrm{mL}-1<\mathrm{MIC}<1500 \mu \mathrm{g} \mathrm{mL}^{-1}$ and low inhibition: MIC $>1600 \mu \mathrm{g} \mathrm{mL}^{-1}$. On the basis of this classification, the seed extract exerts a strong inhibitory activity on all tested bacteria. Alsothe extract showed the highest growth inhibition for $Y$. ruckeri and P. putida (67.5 $\pm 3.53,60 \pm 8.48 \%$ respectively) (Fig.2). Also, MBC assay performed as an adjunct to the MIC showed that $P$. harmala extract in the higher concentrations of $0.8 \mathrm{mg} \mathrm{mL}^{-1}$ for $P$. puti$d a$ and $Y$. ruckeri and $1.1 \mathrm{mg} \mathrm{mL}^{-1}$ for L. garvieae and A. hydrophila was bactericidal (Table3). The comparison of MICs and MBCs values allows a better evaluation of antibacterial effect of bioactive compounds. According to Biyiti, Meko and Amvam Zollo (2004), a substance is bactericidal when the ratio $\mathrm{MBC} / \mathrm{MIC} \leq 2$, and bacteriostatic if the ratio $\mathrm{MBC} / \mathrm{MIC}>2$. The MIC and MBC are often near or equal values; therefore, it can be concluded that seed extract of $P$. harmala has a bactericidal effect on the mentioned bacteria. These results are comparable with other studies in rainbow trout (Fereidouni et al. 2013) which have been reported that in three methods used for extraction of the eight medicinal plants in this study the highest level of antibacterial activity was demonstrated by the essential oil of the leaves of Satureja bachtiarica, the methanol extract of $P$. harmala, the ethanol extracts of Juglans regia and Trachys permum copticum. Accordingly, they are potential source of natural antibacterial against L. garvieae isolated from rainbow trout (Fereidouni et al. 2013).

So far, several alkaloids with pharmaceutical activity including harmine, harmane, harmalol, harmaline, vasicine, vasicinon and peganine have been extracted from the various parts of this plant (Fathiazada, Azarmi \& Khodaie 2006; Goel et al. 2009). It has been reported that harmane as a highly aromatic planar alkaloid exerts its antibacterial activity through interchalate with DNA (Cowan 1999). Thus, this antibacterial mechanism must be considered for active extract of $P$. harmala.

Finally, in this study we report for the first time, the 
antibacterial activity of a seed extract of this plant. The methanol extract of $P$. harmala seed exhibited strong antibacterial activity against these Gram-negative and positive bacterium. Therefore, it might be used for disinfection of instruments and rainbow trout raceways. However, further researchis needed to find out the effective use in vivo of the extract with special reference to timing, dosage and method of administration in fish.

\section{References}

Abutbul A., Golan-Goldhirsh A., Barazani O. \& Zilberg D. (2004) Use of Rosmarinus officinalis as a treatment against Streptococcus iniae in tilapia (Oreochromis sp.). Aquaculture 238, 97-105.

Akhlaghi M. \& Sharifi Yazdi H. (2008)Detection and identification of virulent Yersinia ruckeri: the causative agent of enteric redmouth disease in rainbow trout (Oncorhynchus mykiss) cultured in Fars province, Iran. Iranian Journal of Veterinary Research 9, 347-352

Al-Mizrakchi A. (1998) Adherence of mutans Streptococci on teeth surfaces: microbiological and biochemical studies. $\mathrm{PhD}$ Thesis, University of Al-Mustansiriya.

Aligiannis N., Kalpotzakis E., Mitaku S. \& Chinou I. B. (2001) Composition and antimicrobial activity of the essential oils of two Origanum species. Journal of Agricultural and Food Chemistry 49, 4168-4170.

Altınok I., Kayis S. \& Capkin E. (2006) Pseudomonas putida infection in rainbow trout. Aquaculture 261, 850-855.

Amel b., Abdlouahab Y. \& Abdlhakim B. (2012) Assessment of the antibacterial activity of crude alkaloids extracted from seeds and roots of the plant Peganum harmala L. Journal of Natural Product and Plant Resourse 2, 568-573.

Arshad N., Zitterl-Eglseer K., Hasnain S. \& Hess M. (2008) Effect of Peganum harmala or its beta-carboline alkaloids on certain antibiotic resistant strains of bacte- ria and protozoa from poultry. Phytotherapy Research 22, 1533-1538.

Asghari G. \& Lockwood G. B. (2002) Stereospecific biotransformation of $( \pm)$ phenylethyl propionate by cell cultures of 9 L. Iranian Biomedical Journal 6, 43-60.

Austin B. \& Austin D. A. (2007) Bacterial Fish Pathogens:Diseases of Farmed and Wild Fish. Praxis Publishing Ltd, Chichester.

Bektas S. \& Ayik Ö. (2011) Antimicrobial Susceptibility of Pseudomonas Putida Isolated from Rainbow Trout (Oncorhynchus mykiss). Research Journal of Biology Sciences 4, 67-70.

Biyiti L.F., Meko D.J.L. \& Amvam Zollo P.H. (2004) Recherche de lactivité antibactérienne de quatre plantes médicinales Camerounaises. Pharmacologie et Medecine Traditionelle en Afrique 13, 11-20.

Bukhari N., Choi J.H., Jeon C.W., Park H.W., Kim W.H., Khan M.A. \& Leet S.H. (2008) Phytochemical studies of the alkaloids from Peganum harmala. Applied Chemistry 12, 101-104.

Calist C. \& Ruzzi M. (2009) Development of Innovative Molecular Methods for the Detection and the Identification of Pseudomonas spp. in Environmental and Clinical Samples. Bulletin UASVM Animal Science and Biotechnologies $66,1-5$.

Cowan M. (1999) Plant products as antimicrobial agents . Clinical Microbiology Review 12, 564-582.

Darabpour E., Poshtkouhian Bavi A., Motamedi H. \& Seyyed Nejad S.M. (2011) Antibacterial activity of different parts of Peganum harmala L. growing in Iran against multi drug resistant bacteria. EXCLI Journal 10, 252-263.

Dehghani S., Akhlaghi M. \& Dehghani M. (2012)Efficacy of formalin-killed, heat-killed and lipopolysaccharide vaccines against motile aeromonads infection in rainbow trout (Oncorhynchus mykiss). Global Veterinaria 9, 409415. 
Ehsanpour A. A. \& Saadat E. (2002) Plant regeneration from hypocotyl culture of Peganum harmala. Pakistan Journal of Botany 34, 253-260.

Fathiazada F., Azarmi Y. \& Khodaie L. (2006) Pharmacological effects of Peganum harmala seeds extract on isolated rat uterus. Iranian Jornal of Pharmaceutical Sciences 2, 60-81.

Fereidouni M. S., Akhlaghi M. \& Khadem Alhosseini A. (2013) Antibacterial effects of medicinal plant extracts against Lactococcus garvieae, the etiological agent of rainbow trout lactococcosis. International Journal of Aquatic Biology 1, 119-124.

Ghasemi Pirbalouti A., Nikobin Broujeni V., Momenii M., Malekpoor F. \& Hamedi B. (2011) Antibacterial activity of Iranian medicinal plants against Streptococcus iniae isolated from rainbow trout (Oncorhynchus mykiss). Archives of Biological Sciences 63, 59-66.

Goel N., Singh N. \& Saini R. (2009) Efficient in vitro multiplication of Syrian Rue (Peganum harmala L.) using 6-benzylaminopurine pre-conditioned seedling explants. Nature and Science 7, 29-34.

Gudding R., Lilihaug A. \&Evensen O. (1999) Recent developments in fish vaccinology. Veterinary Immunology and Immunopathology 72, 203-212.

Haghighi Karsidani S., Soltani M., Nikbakhat-Brojeni G., Ghasemi M. \& Skall H.F. (2010) Molecular epidemiology of zoonotic streptococcosis/lactococcosis in rainbow trout (Oncorhynchus mykiss) aquaculture in Iran. Iranian Journal of Microbiolog 2,198-209.

John G., Rathna Kumari P. \& Balasundaram A. (2011) Health promoting biochemical effects of three medicinal plants on normal and Aeromonas hydrophila infected Labeo rohita. Journal of Fisheries and Aquatic Science 6, 633-641.

Jorgensen J. H., Turnidge J. D. \& Washington J. A. (1999) Antibacterial susceptibility tests: dilution and disc diffu- sion methods. In: Manual of clinical microbiology (ed. by P.R. Murray, E.J. Barron, M.A. Praller, F.C.Tenover \& R.H.Yolken), pp. 1526-1562. Washington, D.C.

Kelmanson J. E., Jager A. K. \& Van Staden J. (2000) Zulu medicinal plants with antibacterial activity. Journal of Ethnopharmacology 69, 241-246.

Kowser M. M. \& Fatema N. (2009) Determination of MIC and $\mathrm{MBC}$ of selected azithromycin capsule commercially available in Bangladesh. The ORION Medical Journal 32, 619-620.

Mahmoodian M., Jalilpour H. \& Salehian P. (2002) Toxicity of Peganum harmala: Review and a case report. Iranian Journal of Pharmacology and Therapeutics 1, 1-4.

Mirzaie M., Nosratabadi S. J., Derakhshanfar A. \& Sharifi I. (2007) Antileishmanial activity of Peganum harmala extract on the in vitro growth of Leishmania major promastigotes in comparison to a trivalent antimony drug. Veterinary Arhives 77, 365-375.

Moghadam M. S., Maleki S., Darabpour E., Motamedi H. \& Seyyed Nejad S. M. (2010) Antibacterial activity of eight local plant extract in Khouzestan, Iran against mthicillin and cefixine resistant Staphylococcus aureus strains. Asian pacific Journal of Tropical Medicine 3, 262-265.

Mozaffarian V. (1996) Encyclopedia of Iranian plants. Farhang Moaser Publication, Tehran, Iran, (In Persian).

Negi J. S., Singh P. \& Rawat B. (2011) Chemical constituents and biological importance of Swertia: A review. Current Research in Chemistry 3, 1-15.

Ravelo C., Magarinos B., Romalde J. L. \& Toranzo A. E. (2001) Conventional versus miniaturizad systems for the phenotypic characterization of Lactococcus garvieae strains. Bulletin of the European Association of Fish Pathologists 21, 136-144.

Shamsa F., Monsef H. R., Ghamooghi R. \& Verdian Rizi M. R. (2007) Spectrophotometric determination of total alkaloids in Peganum harmala L. using bromocresol 
green. Research Journal of Phytochemisry 1, 79-82.

Sharifiyazdi H., Akhlaghi M., Tabatabaei M. \& Mostafavi Zadeh S.M. (2010) Isolation and characterization of Lactococcus garvieae from diseased rainbow trout (Oncorhynchus mykiss, Walbaum) cultured in Iran. Iranian Journal of Veterinary Research 11, 342-350.

Shonoudam M., Osman S., Salama O. \& Ayoub A. (2008) Toxical effect of Peganum harmala L leaves on the cotton leaf worm, Spodotera littoralis Boised and its parasitoids Microlitis refiventris Kok. Pakistan Journal of Biological Sciences 11, 546-552.

Srinivasan D., Sangeetha N., Suresh T. \& Perumalsamy P. L. (2001) Antimicrobial activity of certain Indian medicinal plants used in folkloric medicine. Journal of Ethnopharmacology 74, 217-220.

Stubbings W. J., Bostock J. M., Ingham E. \& Chopra I. (2004) Assessment of a microplate method for determining the post-antibiotic effect in Staphylococcus aureus and Escherichia coli. Journal of Antimicrobial Chemotherapy 54, 139-143.

Tobback E., Decostere A., Hermans K., Haesebrouck F. \& Chiers K. (2007) Yersinia ruckeri infections in salmonid fish. Journal of Fish Disease 30, 257-268.

Trakhna F., Harf-Monteil C., Abdelnour A., Maaroufi A. \& Gadonna-Widehem P. (2009) Rapid Aeromonas hydrophila identification by TaqMan PCR assay: comparison with a phenotypic method. Letters in Applied Microbiology 49, 186-190.

Yousefi R., Ghaffarifar F. \& Dalimi A. (2009) The effect of Alkanna tincturia and Peganum harmala extracts on Leishmania major (MRHO/IR/75/ER) in vitro. Iraninan Journal of Parasitology 4, 40-70.

Zampini I. C., Vattuone M. A. \& Isla, M. I. (2005) Antibacterial activity of Zuccagnia punctata Cav. ethanolic extracts. Journal of Ethnopharmacology 102, 450-456. 


\section{فعاليت ضدباكتريايى عصاره متانولى دانه اسيند در برابر باكترىهاى بيماريزاى

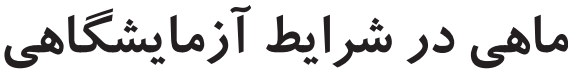

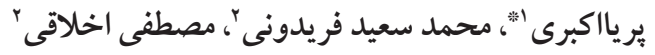

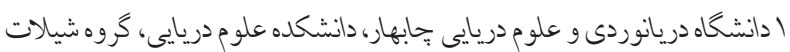

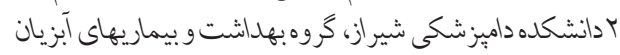

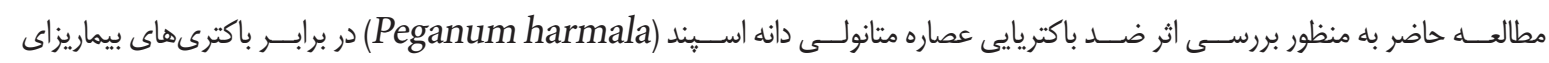

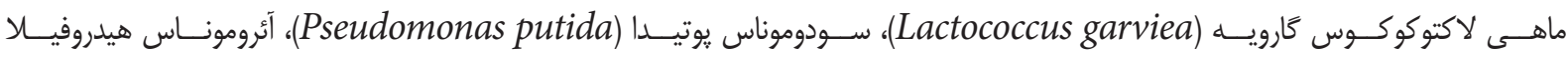
و و يرســينيا راكرى (Aeromonas hydrophila)

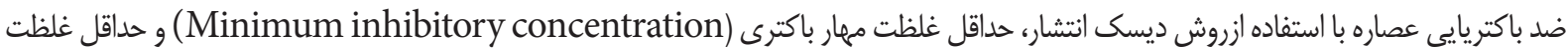

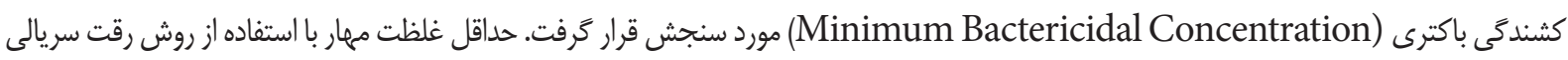

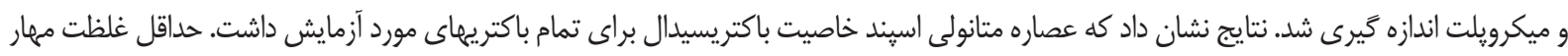

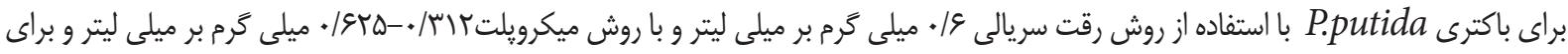

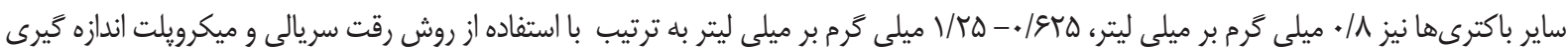

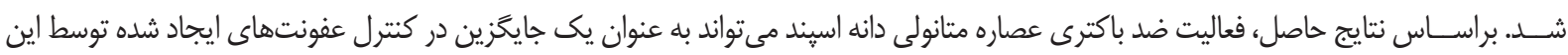
ميكروار كانيسمها در ماهيان كَردد.

وازههاى كليدى: Peganum harmala،عصاره دانهباكترىهاى بيماريزاى ماهى،فعاليت ضد باكتريايى. paria.akbary@gmail.com : 